Equalita, Vol. 1 Issue 1, Agustus 2019

Avaliable online at http://syekhnurjati.ac.id/jurnal/index.php/equalita/article/view/5162

Diterbitkan oleh Pusat Studi Gender dan Anak LP2M IAIN Syekh Nurjati Cirebon, Indonesia

\title{
PERAN RUMAH KITAB DALAM PENCEGAHAN KAWIN ANAK DI INDONESIA
}

\section{Maimunah Mudjahid}

IAIN Syekh Nurjati Cirebon maimunahmudjahid@gmail.com

- Received: 15 Juli 2019 •Accepted: 12 Agustus 2019 •Published online: 30 Agustus 2019

Abstract: This study is to examines the role of Social organization, Rumah Kitab in bringing social change for eradicating child marriage in Indonesia. Yayasan Rumah Kitab is a research institute for policy advocacy to fight for human rights of marginalized people such as women, people with disabilities, religious-race-minorities who are discriminated against by gender-biased religious views. The organization focus study is devoted to policy advocacy and organizing using gender analysis. Rumah KitaB works through research, critical religious texts, empowerment of pesantren, organizing women through critical education, educational institutions and marginal people communities. This study is focus on (i) What programs are design for eradicating child marriage and (ii) what is the social force behind the programs.

Keyword: eradicating child marriage, Yayasan Rumah Kitab

Abstrak: Penelitian ini dilakukan untuk menganalisis peran dari organisasi sosial Rumah Kitab. Yayasan Rumah Kitab adalah lembaga riset untuk kebijakan guna memperjuangkan hak-hak kaum termarjinalkan seperti perempuan, orang dengan disabilitas, minoritas suku ras agama yang mengalami diskriminasi akibat pandangan sosial keagamaan yang bias gender. Kajian Rumah KitaB ditujukan untuk advokasi kebijakan dan pengorganisasian dengan menggunakan analisis gender dan feminisme. Rumah KitaB bekerja melalui riset, kajian teks keagamaan kritis, pemberdayaan pesantren, pengorganisasian perempuan melalui pendidikan kritis, lembaga pendidikan dan komunitas warga marjinal. Fokus dari kajian ini adalah (i) program apa yang didesain untuk menghapuskan perkawinan anak dan (ii) apa yang melatar belakangi program tersebut.

Kata Kunci: penghapusan perkawinan anak, Yayasan Rumah Kitab

\section{A. PENDAHULUAN}

Mahkamah Konstitusi (MK) memerintahkan DPR untuk merevisi UU Perkawinan soal batas usia pernikahan anak. Lantaran Indonesia sudah masuk dalam kondisi 'Darurat Perkawinan Anak'. MK menyebut data pernikahan anak semakin meningkat. Hal itu dilihatnya dari data BPS tahun 2017. Sebaran angka perkawinan anak di atas 25 persen berada di 23 provinsi dari 34 provinsi di Indonesia. Lebih lanjut dikatakan 


\section{Maimunah Mudjahid}

bahwa kondisi ini tentu sangat mengkhawatirkan karena anak telah kehilangan hak-hak yang seharusnya dilindungi oleh negara dan jika kondisi ini dibiarkan tentu akan menjadikan Indonesia berada dalam kondisi 'Darurat Perkawinan Anak' dan tentu saja akan semakin menghambat capaian tujuan bernegara sebagaimana termaktub dalam Pembukaan UUD $1945 .^{1}$

Data Badan Pusat Statistik menunjukkan bahwa dalam 5 tahun terahir, jumlah perkawinan anak tidak mengalami penurunan yang signifikan. Hingga tahun 2015, data menunjukkan sekitar 11\% atau 245.000 adalah perkawinan di usia 10-15 tahun. Selanjutnya, derdasarkan data Survei Sosial Ekonomi Nasional (Susenas) 2016, satu dari sembilan anak menikah di bawah 18 tahun, usia yang saat ini menjadi batas minimal seseorang kawin. Dalam satu hari ada 375 anak menikah. Selain itu, masih dari sumber yang sama Survei Sosial Ekonomi Nasional (Susenas) 2017 dari Badan Pusat Statistik memperlihatkan bahwa dua dari lima anak perempuan usia 10-17 tahun, pernah menikah sebelum usia 15 tahun. Secara total, satu dari sembilan anak perempuan di Indonesia menikah sebelum berusia 18 tahun. Artinya 22,91 persen perempuan di Indonesia melakukan praktik perkawinan anak. Sementara itu, di salah satu wilayah dampingan Rumah KitaB yaitu Jakarta, Remaja perempuan di Jakarta yang menikah di usia 15-19 tahun sebanyak 3,3\%, dengan jumlah angka absolut mencapai 12.520 remaja.

Berdasarkan hasil penelitian yang dilakukan oleh Rumah Kita(b) terdapat alasan yang berbeda yang menjadi penyebab terjadinya pernikahan anak, seperti persoalan ekonomi, interpretasi agama, juga adat dan budaya. Faktor ekonomi keluarga merupakan salah satu faktor utama yang mendorong orang tua menikahkan anak mereka pada usia yang masih relatif muda. Hal ini bertujuan untuk membebaskan keluarga dari tanggungan menafkahi dan membiayai anak perempuan. Salah satu contohnya adalah di daerah Kalibaru Cilincing yang merupakan salah satu wilayah dampingan Rumah KitaB yang berlokasi di Jakarta Utara. Daerah ini merupakan salah satu daerah miskin di Jakarta. Beberapa faktor penyebab kemiskinan adalah rendahnya skill yang dimiliki masyarakat setempat, kepadatan penduduk, angka putus sekolah yang tinggi, pendapatan rendah, ekspanasi industry besar. Hal ini menyebabkan tingginya pernikahan yang dilakukan secara sirri oleh remaja salah satunya. Alasan mereka memilih menikah sirri karena memudahkan mereka jika terjadi perceraian. Contoh lainnya adalah seorang anak yang menikah karena bapaknya mengalami stroke. Pihak keluarga ahirnya memutuskan untuk menikahkan anak perempuan untuk

\footnotetext{
${ }^{1}$ https://news.detik.com/berita/d-4342214/mk-indonesia-darurat-perkawinan-anak
} 


\section{Maimunah Mudjahid}

mengurangi beban ekonomi. Alasan lain orang tua menikahkan anaknya adalah untuk menghindari zina. Untuk alasan menghindari zina, pernikahan seolah menjadi satusatunya penyelesaian atas persoalan tersebut. Pernikahan anak masih menjadi pilihan banyak orang tua dalam mengatasi persoalan pergaulan dan bukan dengan jalan memperbaiki sistem pendidikan agar anak dapat terhindar dari perbutan yang dapat membahayakannya termasuk zina.

Pernikahan anak membawa dampak negatif bagi perempuan itu sendiri seperti menyebabkan rendahnya tingkat pendidikan perempuan, tingginya angka kekerasan yang dialami perempuan atau KDRT juga persoalan kesehatan reproduksi serta persoalan sosial lainnya. Terkait dampak terhadap kesehatan reproduksi, Catahu Komnas Perempuan pada tahun 2018 menyatakan dalam laporan tahunannya bahwa pernikahan anak berpeluang besar menyebabkan kehamilan pada usia belia dan menghadapi resiko yang lebih tinggi dalam hal komplikasi kehamilan dan melahirkan.

Program-program yang dilakukan oleh Rumah KitaB bertujuan menyelesaikan persoalan sosial terkait kawin anak dengan melalui serangkaian kegiatan seperti pelatihan, workshop, penelitian dan penerbitan buku hasil penelitian. Beberapa program, penelitian, penulisan dan publikasi yang dilakukan oleh Rumah KitaB menunjukkan kontribusi dari lembaga ini terhadap penyelesaian persoalan sosial terkait Kawin Anak.

\section{B. METODOLOGI}

Pendekatan yang digunakan dalam paper ini adalah kualitatif melalui analisis dokumen serta produk-produk tertulis seperti buku, laporan serta berita terkait program yang dilakukan oleh Rumah KitaB.

\section{HASIL DAN PEMBAHASAN}

\section{Buku Fikih Kawin Anak sebagai Upaya Pencegahan Kawin Anak}

Sejak tahun 2010, Rumah KitaB telah aktif melakukan penelitian, penulisan, dan penerbitan tentang Kawin Anak. Beberapa produk buku yang dihasilkan oleh lembaga ini tentang pencegahan kawin anak ditulis berdasarkan hasil penelitian dan pengkakian yang dilakukan oleh Tim Rumah KitaB. Dalam tulisan ini akan dibahas beberapa dua buku yang ditulis oleh Tim Rumah KitaB yang secara detail menjelaskan tentang persoalan hukum khususnya hukum Islam atau fikih tentang kawin anak. Buku yang berjudul Fikih Kawin Anak mengetengahkan perdebatan interpretasi agama oleh dua 


\section{Maimunah Mudjahid}

kelompok, yaitu kelompok pendukung dan penentang kawin anak. Bagi kelompok yang mendukung kawin anak, mereka al-Qur'an Hadist, dan Ijma ulama sebagai landasan dasar argumennya dalam menyikapi kawin anak. Selain mengutip ayat al-Qur'an, kelompok pendukung juga banyak menggunakan dalil-dalil yang mengijinkan kawin anak seperti Hadist berikut ini yang dikutip oleh Arif ibn Ahmad yang berbunyi 'Tiga hal akan memberikan pertolongan [kepada manusia], yaitu jihad di jalan Allah, kewajibankewajiban yang ditunaikan, dan pernikahan yang berahir bahagia dan penuh kasih sayang", [HR. al-Tirmidzi]. Argumen lain selain Hadist yang sering digunakan kelompok pendukung salah satunya adalah pendapat yang menyatakan bahwa Nabi Muhammad Saw menikah ketika Sayyidah Aisyah ra. berusia 6 tahun dan hidup bersama setelah usia Sayyidah Aisyah ra.9 tahun.

Oleh kelompok penentang kawin anak, mereka menyatakan bahwa dalil-dalil yang kerap digunakan oleh kelompok pendukung yang dianggap sebagai dalil qath'iy sesungguhnya adalah dalil-dalil yang bersifat kemungkinan yang tidak serta merta bermakna diperbolehkannya perkawinan anak. Selain itu, dikatakan bahwa meskipun imam keempat madzab menyatakan bahwa perkawinan anak kecil laki-laki (al-shaghir) dengan anak perempuan (al-shaghirah) diperbolehkan tetapi ada juga pendapat lain dari Ibn Syabramah, Ibn Hazm, Abu Bakar al A'sham serta Utsman al-Batthi yang menyatakan tidak boleh menikahkan putrinya yang masih kecil. Pendapatnya tersebut merujuk pada al_Qur'an Surat An-Nisa ayat 6 tentang menikahkan anak yatim setelah mereka cukup umur (baligh) bagi orang yang dipercaya untuk menjaga harta anak yatim. Ayat tersebut menurut kelompok penentang pernikahan anak menunjukkan bahwa kedewasaan atau bulugh adalah syarat sahnya pernikahan. Jika baligh bukan syarat pernikahan maka tidak ada makna kata baligh dalam ayat tersebut. Kelompok penentang selain merujuk pada Al-Qur'an, Hadist dan Ijma Ulama juga menggunakan dua metode lain yaitu metode tarjih, selain ushul fikih dan maqâshid syarî́ah. Tarjih adalah penyeleksian berbagai pendapat ulama dan dikukuhkan pendapat yang lebih kuat dari pendapat yang ada.

Selanjutnya, tentang pernikahan Rasulullah Saw dengan Sayyidah Aisyah ra., dikatakan bahwa pernikahan tersebut terjadi ketika Sayyidah Aisyah ra. berusia 6 tahun dan menggaulinya di usia 9 tahun. Namun, hal ini masih perdebatan. Dalam shahih Bukhari dikatakan berusia 6 tahun sementara dalam shahih Muslim disebutkan berumur 7 tahun bahkan ada yang berpendapat Sayyidah Aisyah ra. berumur 18 tahun. Maka, ini berarti bahwa persoalan umur dalam hal ini masih merupakan perkiraan. Terkait hal 


\section{Maimunah Mudjahid}

tersebut, Hadist lain menyebutkan tentang kata mampu (al-ba'ah). Kata ini tidak diartikan secara sempit sebagai kemampuan dalam hal membiayai pesta penikahan namun juga mampu dalam konteks yang lebih luas yaitu kemampuan secara fisik, mental, pendidikan dan lainnya. Oleh karenanya, pada bagian tentang perdebatan tentang hukum kawin anak dijelaskan bahwa sesungguhnya hukum perkawinan tidak tunggal, bisa sunnah, wajib, dan bahkan bisa haram. Penjelasan lain yang dimunculkan adalah pendapat seluruh ulama dalam kitab kuning menyatakan perkawinan yang akan menimbulkan madharat pada pasangan perempuan atau madharat bagi kedua pasangan adalah haram. Contohnya yang disebutkan di dalam buku tersebut adalah ketika sang wali mengawinkan putrinya dengan lelaki tua renta dan pikun sehingga akan berdampak negatif bagi masa depan rumah tangganya.

Contoh lain dari dampak madharat dari perkawinan anak adalah pada persoalan kesehatan. Seperti yang telah disebutkan pada bagian atas, Komnas Perempuan pada tahun 2018 menyatakan dalam laporan tahunannya bahwa Pernikahan anak berpeluang besar menyebabkan kehamilan pada usia belia dan menghadapi resiko yang lebih tinggi dalam hal komplikasi kehamilan dan melahirkan. Tidak hanya itu, hamil dan menikah pada usia belia berkontribusi pada tingginya angka kematian ibu melahirkan (AKI). Saat ini AKI Indonesia adalah salah satu yang tertinggi yaitu 359/100.000 kelahiran hidup.

Namun hal ini tetap tidak menghentikan praktik perkawinan anak. Pada tahun 2010 terdapat 12,26\% perempuan yang menikah pertama kali pada usia 10-15 tahun dan 32,46\% pada usia 16-18 tahun (Trend Indikator Sosial Ekonomi Indonesia, 2012). Dengan demikian total hampir $45 \%$ perempuan Indonesia menikah pertama kali saat mereka di bawah usia 19 tahun.

Rumah KitaB melalui buku Fikih Kawin Anak mencoba untuk tidak memisahkan

fikih dari realitas yang ada serta menempatkan fikih sebagai sumber hukum yang responsif terhadap persoalan sosial dengan cara menyajikan alternatif pandangan yang berbeda dengan tetap menggunakan al-Qur'an, Hadist, dan Ijtima Ulama. Misalnya dalam persoalan pernikahan anak, jika setelah dikaji dan di analisis dengan pendekatan maqâshid al-syarî̀ah, ushul fikih ternyata membawa dampak negatif (madharat) dan dapat membuat kerusakan (mafsadah), maka hal tersebut adalah haram. Pendekatan yang dilakukan oleh Rumah KitaB dengan cara membaca kembali teks-teks keagamaan yang ada merupakan bentuk penyelesaiannya persoalan sosial yang ada. Tujuan utamanya adalah adanya perubahan cara pandang sehingga kemudian mengarah terjadi perubahan sosial, adat dan budaya kearah yang lebih baik. 


\section{Penyelesaian Kasus Pernikahan Anak melalui Penegakan Hukum}

Berdasarkan Catahun Komisi Nasional Perempuan tahun 2018, ditemukan sejumlah 12.504 kasus dispensasi pernikahan. Hal ini meningkat dari tahun sebelumnya pada tahun 2017 yang berjumlah 11.819 kasus. Kenaikan ini patut menjadi perhatian. Artinya, tahun 2018 terdapat 12.504 perkawinan di bawah umur atau perkawinan anak yang disahkan oleh Negara.

Dalam buku yang berjudul Fikih Perwalian, Rumah KitaB kembali mencoba menjawab persoalan tentang tingginya pernikahan anak yang salah satu penyebabnya adalah masalah dispensasi. Dispensasi kawin artinya keringanan yang diberikan pengadilan agama kepada calon mempelai yang belum cukup umur untuk melangsungkan perkawinan. Dispensasi ini diatur dalam UU nomor 1/1974 tentang perkawinan pasal 7 sebagai berikut: (1) Perkawinan hanya diizinkan jika pihak pria sudah mencapai umur 19 (sembilan belas) tahun dan pihak wanita sudah mencapai umur 16 (enam belas) tahun; (2) Dalam hal penyimpangan terhadap ayat (1) pasal ini dapat meminta dispensasi kepada Pengadilan atau Pejabat lain yang ditunjuk oleh kedua orang tua pihak pria maupun pihak wanita.

Undang-Undang (UU) Nomor 7 Tahum 1974 tentang Perkawinan menjadi salah satu penyebab utama maraknya perkawinan anak karena memiliki celah yang dapat digunakan untuk melegalkan perkawinan anak. Dalam Pasal 7 Ayat (1) dan (2) UU Perkawinan menjelaskan soal dispensasi dari pihak orang tua ke pengadilan menjadi penyebab perkawinan anak bisa dilegalkan oleh Kantor Urusan Agama (KUA). KUA sebagai lembaga pemerintah dapat menolak permohonan perkawinan pada tahap administrative awal terkait batas umur perkawinan. Namun, tetap saja keputusan utama ada di pengadilan jika pihak pemohon perkawinan meminta dispensasi dan disetujui pengadilan maka KUA harus menghormati keputusan tersebut dan melegalkanya. Oleh karenanya, pihak KUA tidak memiliki kuasa untuk menolak. ${ }^{2}$

Persoalan dispensasi memiliki keterkaitan erat dengan konsep wilâyah dan qiwâmah. Kedua terma tersebut yang melahirkan hubungan asimetrisme antara laki-laki dan perempuan. Hasil kajian ini kemudian dituangkan menjadi buku "Fikih Perwalian: Membaca Ulang Hak Perwalian untuk Perlindungan Perempuan dari Kawin Paksa dan Kawin Anak." Kajian dilakukan karena hampir semua argumen keagamaan fikih yang terkait dengan praktik perkawinan anak berpusat kepada hak ayah (wilâyah), sementara yang terkait dengan fungsi perlindungan

\footnotetext{
${ }^{2}$ https://rumahkitab.com/kemenag-uu-sebabkan-maraknya-perkawinan-anak/
} 
berpusat kepada lelaki dalam perannya sebagai suami (qiwâmah). Dalam kajian wilâyah dan qiwâmah ini Tim Rumah KitaB mendasarkan argumennya pada alQur’an, hadits, karya-karya para ulama dengan menggunakan metodologi pembacaan teks maqâshid al-syarî̀ah, ushul fikih dan gender. Dengan ketiga pisau analisis ini, argumentasi yang kokoh dibangun guna menolak penafsiran yang selama ini diarahkan untuk memperkokoh asimetrisme relasi laki-laki dan perempuan yang banyak menyumbang pada buruknya status sosial, ekonomi, dan politik perempuan. Buku ini berusaha mendudukkan pemahaman umat Muslim dan sumbangan dari pengalaman Islam di Indonesia terhadap tujuan kemaslahatan syariat dalam masalah hak ijbâr orangtua (ayah) atau wali mujbir dalam perkawinan dan meluruskan pemahaman-pemahaman subyektif bias gender yang tidak mempertimbangkan kepentingan masa depan anak-anak perempuan. ${ }^{3}$

Wali mujbir kerap diartikan sebagai hak orang tua untuk memaksa anak untuk melakukan pernikahan. Pada ahirnya, wali mujbir menjadi sebuah doktrin otoritas yang menegaskan otoritas orang tua terhadap anaknya (Ali, Mukti., Gunawan, Roland., dan Mohammad, Jamaluddin, 157). Karena pandangan teologis tersebut, maka tidak mengagetkan jika Catahu tahun 2018 Komisi Nasional Perempuan (Komnas Perempuan) menyatakan bahwa kasus kekerasan terhadap anak perempuan dalam relasinya sebagai anak diantaranya yang paling dominan adalah pelarangan dalam memilih pasangan hidup. Orang tua kerap meminta dispensasi untuk memaksa anak perempuanya menikah. Dalam draft Undang-undang penghapusan kekerasan seksual yang diserahkan Komnas Perempuan ke DPR RI, Komnas Perempuan memasukkan perkawinan anak sebagai salah satu bentuk pemaksaan perkawinan. Sikap ini diambil karena dalam pandangan Komnas Perempuan, anak haruslah dipandang dalam posisi tidak dapat memberi persetujuan dalam keadaan bebas, ketika berhadapan dengan orang dewasa (orang tua dan keluarga besar) yang menghendakinya menikah.

Pemaknaan atas konsep wali mujbir sebagai seorang yang memiliki hak untuk mengawinkan bahkan dengan cara memaksa menjadi salah satu penyebab tingginya angka perkawinan anak. Landasan teologis dari sikap ini adalah Hadist yang berbunyi 'la nikaha illa bi-waliyyin'. Mazhab al-Syafi'i mengakui bahwa orang tua memiliki haq ijbar (hak memaksa anak perempuannya) dengan syarat-syarat tertentu. Meski demikian, menurut Mazhab Hanafi orang tua tidak memiliki hak ijbar mutlak. Oleh karena itu,

\footnotetext{
${ }^{3}$ https://rumahkitab.com/fikih-perwalian-membaca-ulang-hak-perwalian-untuk-perlindunganperempuan-dari-kawin-paksa-dan-kawin-anak/
} 


\section{Maimunah Mudjahid}

perempuan baik yang sudah pernah menikah maupun perawan, boleh memilih pasangan sendiri. Peran wali mujbir adalah memberikan pandangan yang baik dan nasihat yang baik kepada putrinya agar menikah dengan laki-laki yang baik dan tidak memaksanya (Ali, Mukti., Gunawan, Roland., dan Mohammad, Jamaluddin, 171).

Masih dari sumber yang sama disebutkan bahwa alasan lain meminta dispensasi nikah pada umumnya karena anak telah melakukan hubungan seksual. Kondisi ini seharusnya disikapi dengan melakukan perbaikan pada sistem pendidikan seksual agar anak mengenali tubuhnya dan dapat terhindar dari risiko melakukan aktivitas seksual. Keinginan keluarga untuk menutupi rasa malu, tidak boleh dilakukan dengan mengurangi hak anak perempuan atas pendidikan (Catahun, Komnas Perempuan, 2018). Pada kenyataannya, wali mujbir, dalam hal ini ayah, dalam beberapa kasus melakukan pemaksaan pernikahan atas anak perempuannya meskipun itu berarti tidak memenuhi atau merampas hak anak terkait pendidikan, pengajaran, dan lainnya, tentunya dengan alasan yang berbeda seperti karena alasan ekonomi maupun karena alasan lainnya.

Mandat untuk memenuhi pendidikan bagi seluruh rakyat tidak terkecuali perempuan dan kelompok marjinal tertuang dalam UUD 45 dan secara khusus telah dimuat dalam pasal 28 c, ayat 1 dan Pasal 31, ayat 1-5 dan Undang-Undang No. 20 Tahun 2003 tentang Sistem Pendidikan Nasional serta Undang-Undang No. 23 Tahun 2003 tentang Perlindungan Anak. Selain itu, Indonesia juga telah meratifikasi berbagai undang-undang dan konvensi Internasional sebagi bentuk komitmen Indonesia di tingkat internasional, seperti Konvensi tentang Penghapusan Segala Bentuk Diskriminasi Terhadap Perempuan atau, Deklarasi Universal Hak-Hak Asasi Manusia, Konvensi Internasional tentang Hak-Hak Ekonomi, Sosial dan Budaya, yang telah diratifikasi melalui UU No 11 tahun 2005, Education for All (pendidikan untuk semua), Sustainability Develomment Goals (SDGs) dan lain-lain. Oleh karena itu, pencegahan pernikahan anak dilakukan sebagai upaya pemenuhan hak pendidikan bagi anak maka dispensasi yang diajukan seharusnya dapat ditolak dengan alasan menyukseskan program belajar 12 tahun. Maka, jika anak menempuh pendidikan selama 12 tahun, dia setidaknya berusia 18 tahun saat lulus pendidikannya.

Menteri Pemberdayaan Perempuan dan Perlindungan Anak Indonesia, Yohana Yembise menyatakan bahwa salah satu sektor yang menunjukkan kesenjangan antara laki-laki dan perempuan adalah pendidikan. Data Badan Pusat Statistik menunjukkan bahwa rata-rata perempuan di Indonesia hanya berpendidikan sampai kelas tujuh atau 


\section{Maimunah Mudjahid}

kelas dua SMP. Masih banyak perempuan yang tidak menyelesaikan pendidikan SMP dan hanya memiliki sertifikat sekolah dasar. Kondisi ini menyebabkan Tingkat Partisipasi Angkatan Kerja (TPAK) perempuan yang masih jauh di bawah laki-laki. Berdasarkan data Sakernas (Survei Ketenagakerjaan Nasional) pada 2017. Tingkat Partisipasi Angkatan Kerja (TPAK) perempuan adalah 50, lebih rendah dibandingkan laki-laki yang sudah mencapai $83 .{ }^{4}$ Artinya, pernikahan anak akan semakin membuat posisi perempuan tergantung secara ekonomi kepada orang lain dalam hal ini suami, dan hal ini akan berdampak pada tingkat kemiskinan secara umum.

Lies Marcoes Natsir, direktur Rumah Kitab menyatakan bahwa Ekonomi dan kemiskinan terstruktural menjadi penyebab Indonesia darurat perkawinan anak. Angka perkawinan anak di Indonesia masih tinggi. "Angka perkawinan anak masih tinggi dan penyebabnya multidimensi. Ini terkait dengan ekonomi, terkait dengan kemiskinan struktural,". Berdasarkan pernyataan tersebut dapat kita lihat bahwa pernikahan anak merupakan persoalan sosial yang terhubung dengan berbagai isu lain seperti agama, politik, ekonomi, adat, dan budaya. Maka, dalam penyelesaiannnya perlu mempertimbangkan seluruh aspek tersebut.

Dalam rangka menciptakan pernikahan yang membawa kemaslahatan bagi semuanya, pernikahan selain mensyaratkan adanya wali, juga harus mempertimbangkan keikhlasan dari kedua belah pihak atau taradhin (2018: 173). Argument-argumen yang dihadirkan dalam buku Fikih Kawin Anak menekankan pada kemaslahatan perempuan dengan menggunakan Hadist, al-Qur'an, dan Ijma Ulama. Misalnya, meskipun mazhab al-Syafi'i, mengakui adanya haqq al-ijbar, namun hak tersebut mensyaratkan setidaknya 7 hal yaitu (1) calon suami yang sepadan (kufu), (2) tidak akan membebani dan mudharat bagi kehidupan anak perempuan, (3) memastikan anak perempuannya memiliki rasa cinta terhadap pilihan orang tuanya, (4) as kawin yang sesuai, (5) calon suami tidak keberatan dengan maharnya, (6) tidak ada halangan dan kendala syariat, misalnya calon suami memiliki kewajiban haji (169). Dengan melihat pada hal tersebut, meski orang tua, dalam hal ini ayah memiliki haq ijbar, namun dispensasi tidak harus selalu diberikan. Sebuah perkawinan yang tidak berdasarkan keikhlasan dan tidak mempertimbangkan masa depan serta dapat membahayakan kehidupan perempuan seharusnya tidak dilakukan.

\footnotetext{
${ }^{4}$ (https://www.kemenpppa.go.id/index.php/page/read/29/1811/tingkatkan-akses-dan-partisipasiperempuan-dalam-pembangunan-ekonomi
} 


\section{SIMPULAN}

Rumah KitaB merupakan salah satu lembaga sosial yang bergerak dibidang pengkajian dan penelitian yang bertujuan untuk menciptakan tatanan sosial yang adil gender. Dua buku yang diterbitkan oleh Rumah KitaB menjawab persoalan tentang perlunya menimbang ulang pernikahan anak. Rumah KitaB mencoba berkontribusi dalam penyelesaian persoalan sosial yang ditimbulkan karena pernikahan anak. Dalam melakukannya, Rumah KitaB mencoba menyandingkan argument-argumen antara kelompok yang penentang dan pendukung kawin anak, termasuk dalil-dalil yang digunakan oleh masing-masing kelompok. Dengan menggunakan sumber-sumber yang sama, yaitu Al-Quran, Hadist dan Ijma Ulama, perdebatan tentang kawin anak menjadi lebih tajam dengan penggunaan pendekatan ushul fikih dan maqâshid syarî̀ah oleh kelompok penentang kawin anak. Pendekatan yang sama juga digunakan ketika berbicara tentang konsep perwalian. Sampai di sini dapat terlihat bahwa tujuan dari penulisan kedua buku di atas adalah terjadi perubahan cara pandang terhadap masalah kawin anak untuk melahirkan pandangan baru ke arah yang lebih adil. Buku Fikih Perwalian yang memaparkan tafsir ramah perempuan dapat membantu para pembuat keputusan untuk mendapatkan perspektif yang lebih baik dalam membuat keputusankeputusan. Penerbitan buku yang dilakukan oleh Rumah KitaB dapat menjadi rujukan dalam mempertimbangkan ulang pemberian dispensasi pernikahan yang menjadi salah satu penyebab tingginya angka perkawinan anak dan berkontribusi pada persoalan sosial lainnya di Indonesia.

\section{DAFTAR PUSTAKA}

Ali, Mukti., Gunawan, Roland., dan Mohammad, Jamaluddin. 2015. Fikih Kawin Anak; Membaca Ulang Teks Keagamaan Perkawinan Usia Anak-anak. Yayasan Rumah KitaB: Jakarta.

Ali, Mukti., Gunawan, Roland., dan Mohammad, Jamaluddin. 2019. Fikih Perwalian: Membaca Ulang Hak Perwalian untuk Perlindungan Perempuan dari Kawin Paksa dan Kawin Anak. Yayasan Rumah KitaB: Jakarta.

Ali, Mukti., Gunawan Roland., dan Mohammad Jamaluddin. 2018. Kawan dan Lawan Kawin Anak (Catatan Assemen Program Berdaya di Empat Daerah). Yayasan Rumah KitaB: Jakarta.

Ali, Mukti., Gunawan, Roland., Hilmi, Ahmad., Khoiron, Mohammad., Ma'arif, Zainul., Makmur, Jamal.,dan Mohammad Jamaluddin., 2019. Fikih Perwalian; Membaca Ulang Hak Perwalian untuk Perlindungan Perempuan dari Kawin Anak. Yayasan Rumah KitaB: Jakarta. 
Lembar Fakta Catatan Tahunan (CATAHU) Komnas Perempuan Tahun 2018. Tergerusnya Ruang Aman Perempuan dalam Pusaran Politik Populisme. Jakarta: 7

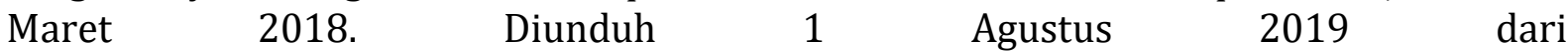
https://www.komnasperempuan.go.id/file/pdf file/2018/SIARAN\%20PERS\%202018/ Lembar\%20Fakta\%20Catahu\%207\%20Maret\%202018.pdf

MK: Indonesia Darurat Perkawinan Anak. Jakarta: 13 Desember 2018. Diunduh pada 1 Agustus 219 dari https://news.detik.com/berita/d-4342214/mk-indonesia-daruratperkawinan-anak

Survei Ekonomi Nasional (SUSENAS) tahun 2017. Jakarta: 23 Agustus 2018. Diunduh 1 Agustus 2019 dari http://microdata.bps.go.id/mikrodata/index.php 